\title{
Metode Pertahanan Web Server Terhadap Distributed Slow HTTP DoS Attack
}

\author{
Molavi Arman \\ AMIK MDP; Jalan Rajawali 14, Palembang - Sumatera Selatan, 30113 \\ Manajemen Informatika, AMIK MDP, Palembang \\ e-mail: molavi.arman@mdp.ac.id
}

\begin{abstract}
Abstrak
Meningkatnya kecepatan internet selalu diikuti meningkatnya pula gangguan keamanan dalam jaringan komputer.Hal ini cukup mengganggu layanan yang terhubung ke jaringan LAN maupun internet. Gangguan keamanan ini dikenal dengan DDoS (Distributed Denial of Service). Serangan DoS slow HTTP adalah salah satu metode serangan DoS yang menargetkan server HTTP. Metode ini menghambat layanan dengan membanjiri sehingga menimbulkan kumpulan koneksi dengan permintaan yang lambat dan banyak menuju web server. Diketahui bahwa serangan slow HTTP DoS oleh satu penyerang dapat dicegah secara efektif dengan membatasi jumlah koneksi untuk setiap alamat IP. Di sisi lain, juga diketahui bahwa sulit untuk bertahan dari serangan slow HTTP DoS dari beberapa penyerang. Ancaman serangan DDoS semakin serius, jadi membutuhkan metode pertahanan yang efektif terhadap serangan DoS slow HTTP terdistribusi. Ketika web server berada di jaringan publik atau internet, maka melindungi komputer dan keamanan jaringan adalah masalah penting. Setelah mengidentifikasi dan menganalisis cara kerja serangan slow HTTP, serta deteksi serangannya, tulisan ini menjelaskan sistem kerja, cara mendeteksi, dan cara mempertahankan diri terhadap serangan slow HTTP.
\end{abstract}

Kata kunci: DDoS, DoS, serangan Slow HTTP, Web Server

\begin{abstract}
The increase in internet speed is always followed by the increase in security disturbances in computer networks. This is quite disturbing to the services connected to the LAN network or the internet. This security disturbance is known as DDoS (Distributed Denial of Service). Slow HTTP DoS attack is one of the DoS attack method that targets HTTP servers. This method inhibits service by flooding, causing a collection of connections with slow and many requests to the web server. It is known that a slow HTTP DoS attack by one attacker can be effectively prevented by limiting the number of connections for each IP address. On the other hand, it is also known that it is difficult to survive a slow HTTP DoS attack from some attackers. The threat of DDoS attacks is getting more serious, so it requires an effective defense method against distributed slow HTTP DoS attacks. When a web server is on a public network or the internet, protecting your computer and network security is an important issue. After identifying and analyzing the workings of slow HTTP attacks, as well as detection of attacks, this paper explains the working system, how to detect, and how to defend against slow HTTP attacks.
\end{abstract}

Keywords : DDoS, DoS, serangan Slow HTTP, Web Server 


\section{PENDAHULUAN}

Terus meningkatnya kecepatan internet dari waktu kewaktu selalu diikuti meningkatnya pula serangan cybercriminals dari tahun ketahuan. Tahun 2018 yang lalu jumlah serangan DDoS terus menurun, membuat para ahli Kaspersky Lab berasumsi bahwa penjahat cyber yang telah melakukan serangan DDoS untuk keuntungan finansial telah mengalihkan perhatian mereka ke sumber pendapatan lain (seperti penambangan crypto). Namun, statistik untuk Q1 2019 bertentangan dengan tren ini dan menunjukkan bahwa jumlah serangan DDoS yang diblokir oleh Kaspersky DDoS Protection telah tumbuh dengan mengejutkan 84\%, jika dibandingkan dengan Q4 2018. [1].

Serangan Denial of Service umumnya dilakukan membanjiri server atau host sehingga host korban kehabisan sumber daya (memori, CPU, lalu lintas). Kondisi ini membuatnya tidak dapat melayani pengguna lain. Floodingatau membanjiri sulit diatasi, tidak cukup hanya dengan me-reboot, seperti serangan lainnya. Ada beberapa varian serangan DoS, tidak kurang dari 35 varian serangan ini. Setiap varian memiliki perbedaan karakteristik dalam hal serangannya,tetapi mereka memiliki hal yang efek yang sama, menimbulkan penolakan layanan. [2]

Perangkat Internet of Things (IoT) yang rentan juga membawa ancaman.IoT adalah sistem yang menghubungkan smart devices ke Internet. Perangkat IoT cenderung memiliki karakteristik berikut [3]: Selalu aktif, bandwidth cukup tinggi, kata sandi lemah, standar tertinggal, siklus pembaruan panjang. Karakteristik ini membuat perangkat IoT yang lemah mudah dibajak dan disalahgunakan untuk meluncurkan serangan DDoS.

Serangan HTTP DoS yang lambat adalah salah satu metode serangan DoS yang menargetkan server HTTP. Metode ini menghambat layanan dengan menjenuhkan kumpulan koneksi dengan permintaan yang lambat dan banyak. Laporan bahwa serangan DoS "slow read" semacam serangan HTTP DoS dari hanya satu penyerang dapat dicegah secara efektif dengan membatasi jumlah koneksi untuk setiap alamat IP, [4] disisi lain juga bahwa sulit untuk bertahan terhadap serangan slowHTTP DoS dari beberapa penyerang (Distributed Slow HTTP DoS Attack).

\section{METODE PENELITIAN}

\subsection{Framework Penelitian}

Metodologi penelitian ini melalui beberapa tahapan yang direpresentasikan dalam suatu kerangka kerja penelitian/framework. Kerangka kerja penelitian secara sistematis menjelaskan langkah penelitian yang meliputi perancangan,pengujian,dan proses analisis. 


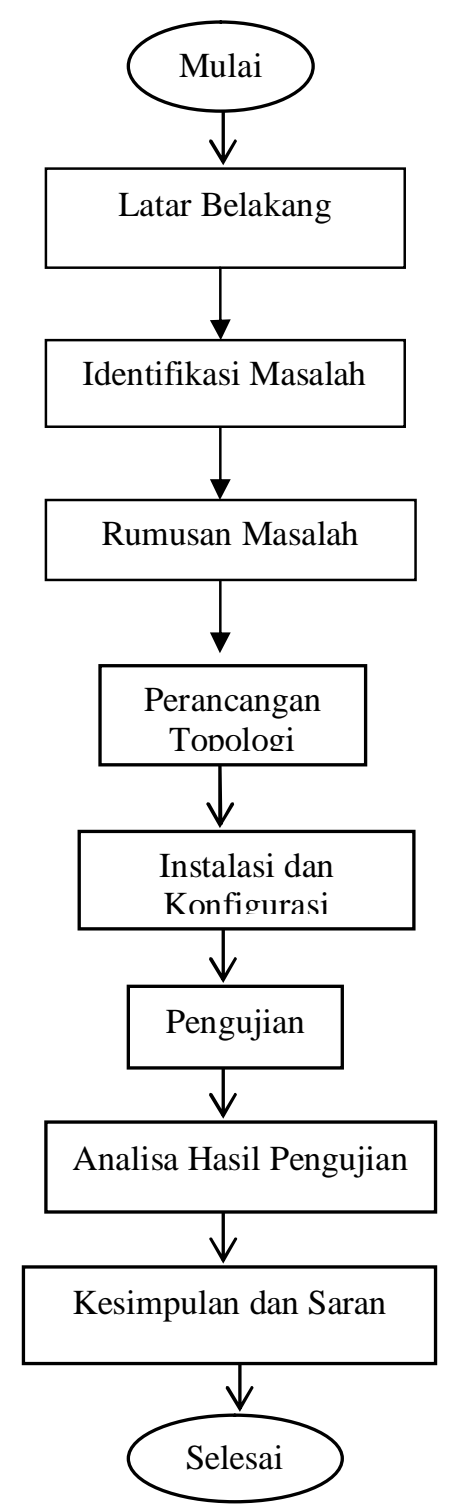

Gambar 1. Diagram Alir Framework Penelitian

Tahapan awal penelitian adalah merancang, membangun topologi kemudian melakukan instalasi dan konfigurasi environment yang dibutuhkan dalam membangun web server.

Penjelasan diagram alir framework adalah sebagai berikut:

a. Menjelaskan latar belakang dengan menngumpulkan penelitian terdahulu, sehingga menjadi landasan dalam penentuan tema.

b. Melakukan indetifikasi masalah yang terjadi dalam menghadapi serangan DDoS.

c. Perancangan topologi. Topologi yang dirancang untuk pengujian dibuat sedemikian rupa sehingga memudahkan dalam pengujian terhadap serangan slowloris atau slow HTTP. 


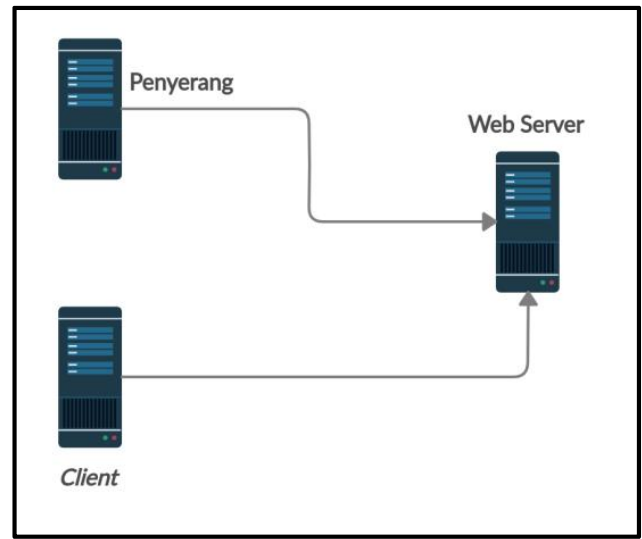

Gambar 2. Topologi Skenario Pengujian

a. Instalasi dan konfigurasi server menggunakan sistem operasi Debian 64 bit dan menggunakan memori sebesar $2 \mathrm{~GB}$, dengan kecepatan processor $3.3 \mathrm{GHz}$.

b. Melakukan pengujian dengan menggunakan toolsslowloris.

c. Pengambilan data diperoleh dari ouput pengujian yang dihasilkan apachectl.

d. Analisa pengujian memisahkan hasil sebelum konfigurasi dan setelah konfigurasi supaya menunjukkan adanya perbedaan terhadap web serveryang diserang menggunakan slowloris dan setelah dilindungi.

e. Kesimpulan dari percobaan bahwa web server menunjukkan respon perubahan setelah dilakukan konfigurasi.

\subsection{HTTP}

Salah satu protokol aplikasi paling populer yang digunakan di Internet adalah HTTP. HTTP adalah singkatan dari "Hypertext Transfer Protocol." HTTP adalah protokol aplikasi yang berjalan di atas protokol TCP / IP. Web menggunakan protokol ini, ketika membuka halaman web, browser mungkin telah mengirim lebih dari 40 permintaan HTTP dan menerima tanggapan HTTP untuk masing-masing. Header HTTP adalah bagian inti dari permintaan dan respon HTTP, dan proses membawa informasi tentang browser klien, halaman yang diminta, server, dan lainnya.

Seperti yang diilustrasikan dalam gambar 3, klien HTTP mengirim pesan permintaan ke server HTTP.Server, pada gilirannya, mengembalikan pesan respon. [5].

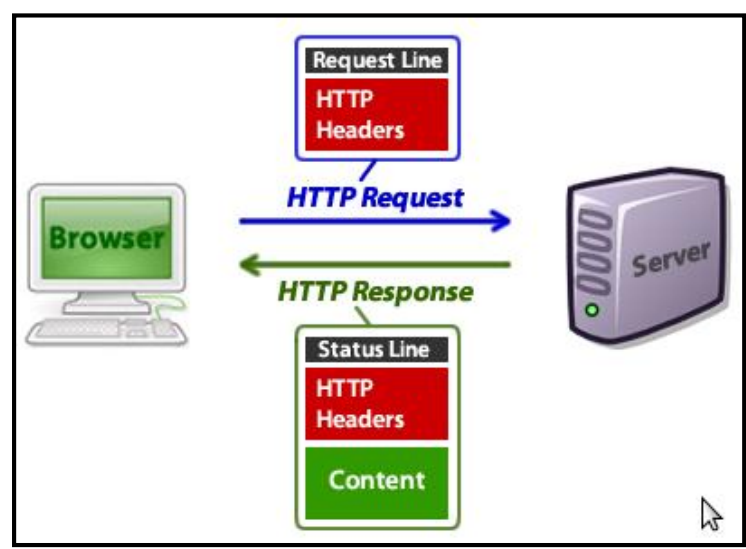

Gambar 3. HTTP Request dan HTTP Response 
Program di sisi klien, yang disebut 'browser'akan melakukan permintaan HTTP ke server. Browserweb adalah klien HTTP. Mesin server Web apa pun berisi file halaman web (teks, gambar grafik, suara, video, dan file multimedia lainnya) dan juga daemon HTTP, program yang dirancang untuk menunggu permintaan HTTP dan menanganinya. Klien perlu mengetik Uniform Resource Locator yang benar (URL) alamat dalam program browser atau mengklik tautan hypertext untuk mendapatkan halaman atau file web, misalnya., https://www.molaviarman.net/index.php. Kemudian browser mengonversi URL menjadi pesan permintaan dan mengirimkannya ke server HTTP. Server daemon HTTP menerima dan menginterpretasikan pesan permintaan, dan mengembalikan file yang disamakan atau file yang terkait dengan permintaan. Proses ini diilustrasikan dalam gambar 4 di bawah ini:

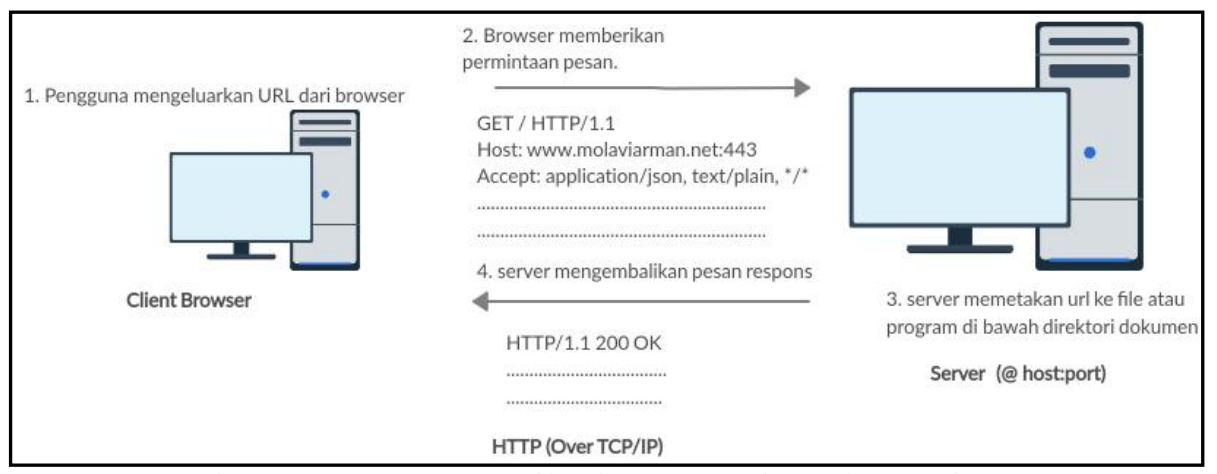

Gambar 4. Proses Komunikasi Antara Client dan Web Server

Seperti yang disebutkan di atas, ketika klien memasukkan URL di kotak alamat browser, browser menerjemahkan URL menjadi pesan permintaan HTTP dan mengirimkannya ke server. Misalnya, browser menerjemahkan URL https://www.molaviarman.net/index.php menjadi pesan permintaan, seperti yang ditunjukkan gambar 5 di bawah ini:

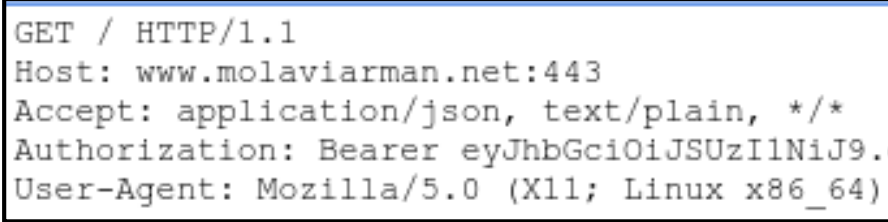

Gambar 5. Pesan Permintaan HTTP GET dari Terjemahan URL

Ketika pesan permintaan ini diterima dan ditafsirkan oleh server, server akan melakukan salah satu dari tiga tindakan:

- Server, server akan melakukan salah satu dari tiga tindakan: Server mencari file di bawah dokumen server direktori dan mengembalikan file yang diminta.

- Server menjalankan program yang diminta dan mengembalikan output program ke klien.

- Server mengembalikan pesan kesalahan, karena permintaan tidak bisa dipenuhi.

Contoh pesan respons HTTP adalah seperti yang ditunjukkan gambar 6 di bawah ini: 


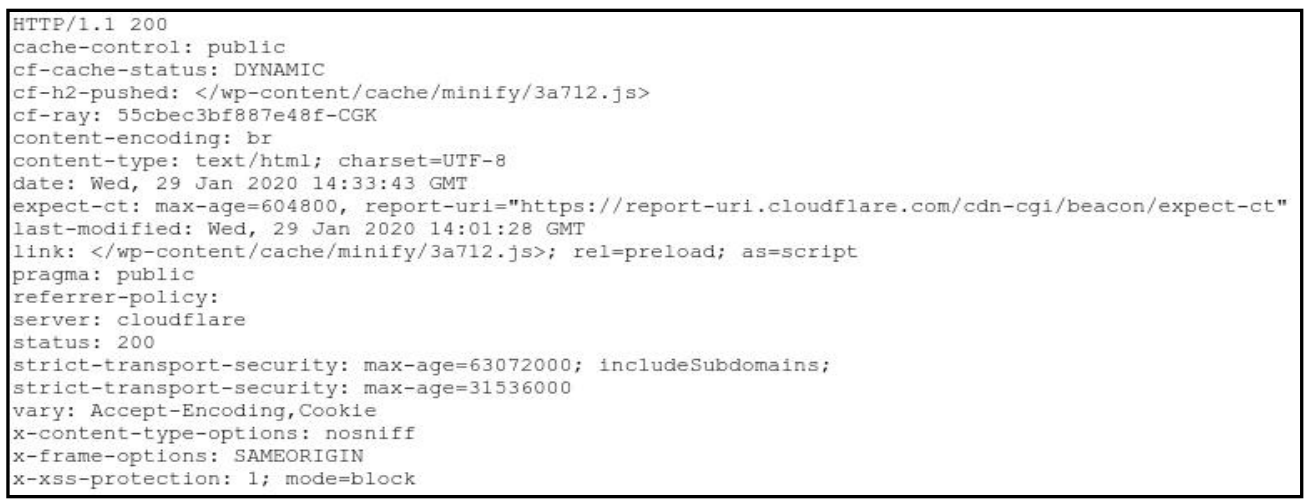

Gambar 6. Pesan Respon HTTP

Program browser menerima, menafsirkan, dan menampilkan isi pesan respon di jendela browser sesuai dengan tipe konten. Contoh di atas, konten - jenisnya adalah teks / html. Ada banyak jenis konten, seperti "teks / teks", "teks / html", "audio / mpeg", "video / mpeg", "image / gif", "image / png", "image / jpeg", "application / pdf", dan lain-lain.

\subsection{Denial of Service}

Serangan DoS adalah ancaman keamanan di mana penyerang mengirimkan sejumlah besar permintaan palsu ke host atau server, sehingga host target menolak akses dari pengguna yang berwenang sehinga layanan dari host menjadi tidak tersedia, oleh karena itu serangan mengganggu ketersediaan sistem. Serangan denial of service (DoS) yang bertujuan untuk pengguna yang sah dalam mengakases internet dan menjadi tantangan yang cukup bagi keamanan jaringan Jika serangan penolakan layanan diluncurkan dari beberapa komputer, sering disebut serangan Distributed Denial of Service (DDoS). Serangan DoS yang paling umum digunakan sekarang adalah serangan DDoS di mana sejumlah besar komputer mengirim ribuan permintaan ke sistem yang sedang diserang. Serangan DDoS terjadi ketika beberapa host terinfeksi dengan malware yang memungkinkan host diambil alih oleh penyerang; kemudian program penyerang memerintahkan mereka untuk mengakses target situs web. Biasanya, host yang menjadi target serangan DoS adalah sistem berbasis web atau server web. Secara umum, program server web, seperti Apache, IIS memiliki kemampuan untuk menangani atau menerima banyak koneksi dari pengguna. Penyerang mendapat keuntungan dari hal tersebut. [6] [7].

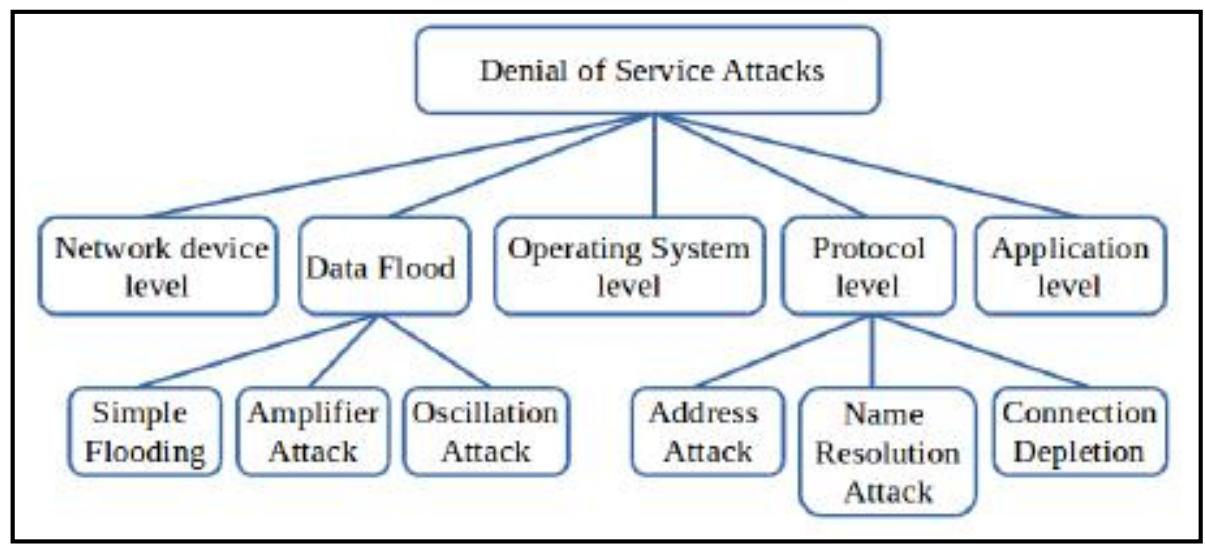

Gambar 7. Klasifikasi Serangan DoS 


\subsection{Slow HTTP DoS Attack}

Slow HTTP Denial of Service (DoS) adalah serangan DoS lapisan aplikasi di mana sejumlah besar permintaan HTTP tidak lengkap dikirim. Ini adalah layer 7 DoS. Serangan aplikasi DoS adalah kelas yang baru dalam serangan DoS yang mengeksploitasi kelemahan dalam desain aplikasi atau implementasinya. Serangan ini lebih sulit dilacak dari pada serangan DoS klasik karena, sebagai berikut:

1. Serangan ini tidak memakan banyak bandwidth.

2. Target ini untuk menciptakan kemacetan dan sumber daya pembatasan dalam aplikasi dengan berfokus pada tautan terlemah dalam aplikasi.

3. Serangan ini biasanya menggunakan https sebagai transportasi mereka untuk menyembunyikan asal mereka yang sebenarnya.

Serangan HTTP lambat terutama dari tiga jenis [8] sebagai berikut:

1. Slow Headers (Slowloris): Dalam serangan Slow Header, seorang penyerang meluncurkan aksinya dengan bantuan alat yang disebut Slowloris atau sejenisnya. Alat ini membuka koneksi, kemudian mengirim header HTTP, menambah tetapi tidak pernah menyelesaikan permintaan. Ribuan koneksi HTTP POST dibuat dan mengirimkan HTTP Header dengan sangat lambat untuk memaksa serverweb target untuk menjaga koneksi tetap terbuka. Koneksi ini akan tetap hidup, tidak terputus dari server target. Slowloris akan mengambil semua sumber daya dari server web target, sehingga memblokir permintaan dari klien yang sah atau klien yang ingin mengakses server web tersebut.

2. Slow Body (R-U-Dead-Yet): Serangan Slow Body bekerja seperti Slow Header. Penyerang dengan bantuan alat yang disebut R-U-Dead-Yet atau sejenisnya mengirim POST Body yang tidak akan berakhir. Tahap serangan dimulai dengan membuat koneksi TCP awal ke server web target. Kemudian mengirimkan headerPOST HTTP terlebih dahulu seperti koneksi normal. Header berisi informasi ukuran tubuh paket data yang akan dikirim berikutnya. Penyerang mengirim isi pesan dengan kecepatan sangat rendah. Tetapi koneksi tetap hidup, membuat server web korban menunggu cukup lama. Koneksi baru dan serupa dibuat dalam jumlah besar, menggunakan semua sumber daya server dan membuat koneksi yang sah menjadi tidak mungkin mengakses.

3. Slow Read: Dalam Serangan Slow Read, penyerang mengirim paket TCP-SYN yang valid untuk membuka koneksi dengan server target. Kemudian sesi yang valid dibuat di antara mereka. Selanjutnya, ia mulai meminta dokumen dari server target. Setelah unduhan dimulai, host penyerang mulai memperlambat pembacaan paket yang diterima. Kondisi ini akan berlanjut dan mengambil semua sumber daya dari server target. Slow Read Attacks selalu menggunakan paket non-spoofed dalam rangka untuk menahan sesi terbuka untuk jangka waktu yang lama.

\subsection{Bagaimana Slow Read Attack Bekerja}

Seperti dijelaskan pada bagian di atas, serangan dilakukan dengan bantuan skrip program, yang mampu mengirimkan permintaan sebagian dari paket data, menjaga beberapa koneksi ke server web korban tetap terbuka. Secara berkala, ia mengirim header HTTP berikutnya, tetapi sengaja tidak pernah selesai. Itu memicu server web korban untuk menyediakan semua sumber dayanya bagi penyerang, yang akhirnya menyangkal koneksi dari pengguna yang sah. Seorang penyerang tidak membutuhkan bandwidth besar untuk menjatuhkan server web korban, tetapi hanya membuat sejumlah besar koneksi [9]. Gambar 8 menggambarkan serangan. 


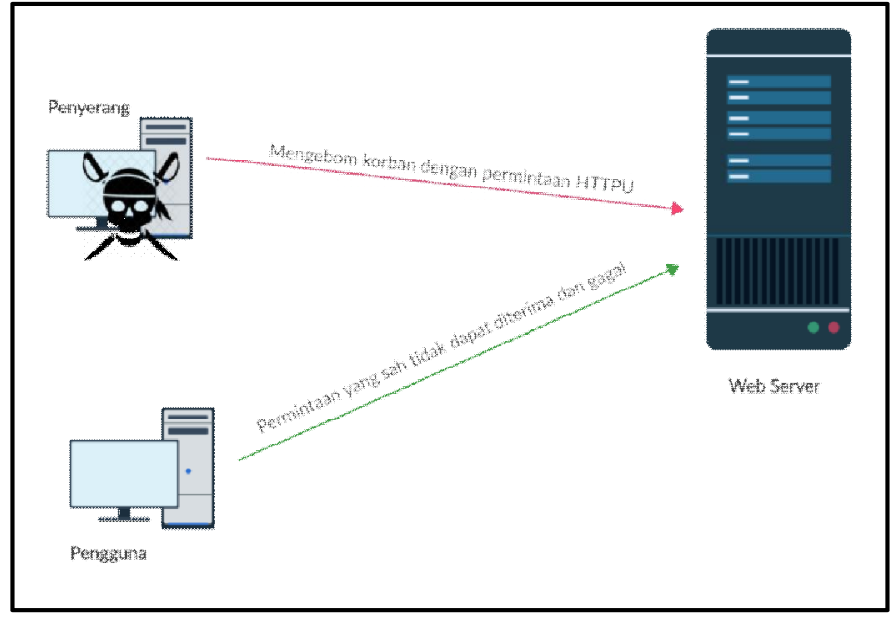

Gambar 8. Ilustrasi Serangan Slow HTTP

Pesan 'permintaan' dari klien ke server mencakup, dalam baris pertama pesan itu, metode yang akan diterapkan pada sumber daya, pengidentifikasi sumber daya, dan versi protokol yang digunakan. Protokol HTTP mendefinisikan seperangkat metode permintaan. Metode yang digunakan adalah HEAD, GET, POST, PUT, DELETE, TRACE, CONNECT dan OPTION. Kami dapat melakukan analisis permintaan HTTP GET dari klien ke serveweb server. Analisis ini akan membantu dalam penjelasan lebih lanjut tentang permintaan GET HTTP. Alat, seperti Firebug, Live Header HTTP Langsung diperlukan untuk membantu analisis [11]. Ekstrak melengkapi permintaan GET HTTP seperti yang ditunjukkan gambar 9 di bawah ini:

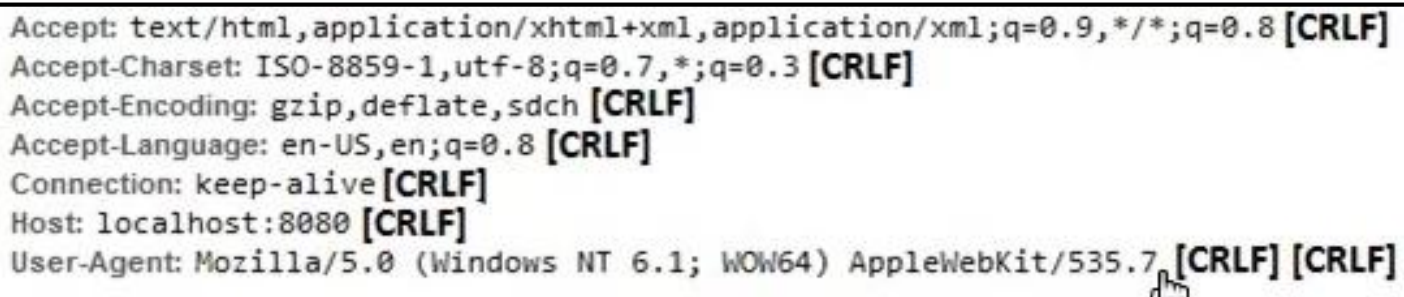

Gambar 9. Contoh Header HTTP request

Contoh di atas adalah Header GET normal. Setiap baris pesan berakhir dengan CRLF karakter. CRLF adalah kependekan dari CR (Carriage Return) dan LF (Line Feed). CRLF adalah karakter yang tidak dapat dicetak. Pesan permintaan berakhir dengan baris kosong. Ada dua karakter CRLF di baris bawah. Mereka bersama digunakan untuk menunjukkan suatu baris kosong. [CRLF] di akhir pesan permintaan menarik perhatian penyerang.

Dalam serangan slow HTTP, garis kosong tidak akan pernah ada. Penyerang sengaja tidak mengirim karakter CRLF, di akhir permintaan. Pesan permintaan sebagai berikut ini akan menghasilkan serangan slow HTTP, karena keberadaan tag CRLF tunggal di akhir menunjukkan header tidak lengkap, dan server perlu menunggu header lengkap. Sampel header yang tidak lengkap ditunjukkan pada gambar 10 di bawah ini: 


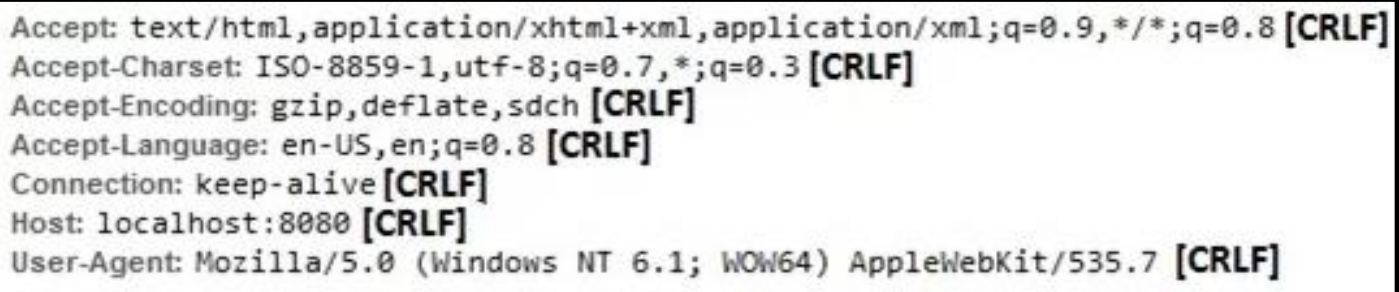

Gambar 10. Header Permintaan HTTP Tidak Lengkap Dengan Slow HTTP Attack

\subsection{Identifikasi dan Pengujian Serangan Slow HTTP}

Efek dari serangan Slow HTTP adalah bahwa semua klien tidak dapat terhubung ke server web. Situs tidak mau memuat dan klien tidak akan pernah bisa melihat konten halaman web. Jika server web diserang, akan melihat banyak koneksi pada port 80 dari IP sumber. Perintah netstat dapat menampilkan daftar koneksi seperti gambar 11 berikut:

\# perl slowloris.pl -dns 192.168.1.90

Welcome to Slowloris - the low bandwidth, yet greedy and poisonous HTTP client by Laera Loris

Defaulting to port 80 .

Defaulting to a 5 second tcp connection timeout.

Defaulting to a 100 second re-try timeout.

Defaulting to 1000 connections.

Multithreading enabled.

Connecting to $192.168 .1 .90: 80$ every 100 seconds with 1000 sockets:

Building sockets.

Building sockets.

Building sockets.

Sending data.

Current stats: Slowloris has now sent 383 packets successfully.

This thread now sleeping for 100 seconds...

Sending data.

Current stats: Slowloris has now sent 589 packets successfully.

This thread now sleeping for 100 seconds...

Building sockets.

\# netstat -nalt | grep :80

\begin{tabular}{|c|c|c|c|c|}
\hline tсp6 & 0 & 0 192.168.1.90:80 & 192.168.1.91:39354 & ESTABLISHED \\
\hline tcp6 & 0 & 0 192.168.1.90:80 & 192.168.1.91:39390 & ESTABLISHED \\
\hline tcp6 & 0 & 0 192.168.1.90:80 & 192.168.1.91:39394 & ESTABLISHED \\
\hline tcp6 & 0 & 0 192.168.1.90:80 & 192.168.1.91:39174 & FIN_WAIT2 \\
\hline cp6 & 0 & 0 192.168.1.90:80 & 192.168.1.91:39220 & ESTABLISHED \\
\hline cp6 & 0 & 0 192.168.1.90:80 & 192.168.1.91:39202 & FIN_WAIT2 \\
\hline tcp6 & 0 & 0 192.168.1.90:80 & 192.168.1.91:39188 & FIN_WAIT2 \\
\hline tcp6 & 0 & 0 192.168.1.90:80 & 192.168.1.91:39148 & FIN_WAIT2 \\
\hline cp6 & 0 & 0 192.168.1.90:80 & 192.168.1.91:39298 & ESTABLISHED \\
\hline tcp6 & 0 & 0 192.168.1.90:80 & 192.168.1.91:39154 & FIN_WAIT2 \\
\hline tcp6 & 0 & 0 192.168.1.90:80 & 192.168.1.91:39326 & ESTABLISHED \\
\hline p6 & 0 & 0 192.168.1.90:80 & 192.168.1.91:39362 & ESTABLISHED \\
\hline & 0 & 0 192.168.1.90:80 & 192.168.1.91:39360 & ESTABLISHED \\
\hline p6 & 0 & 0 192.168.1.90:80 & 192.168.1.91:39184 & FIN_WAIT2 \\
\hline p6 & 0 & 0 192.168.1.90:80 & 192.168.1.91:39438 & ESTABLISHED \\
\hline
\end{tabular}

Gambar 11. Pengujian dan Serangan Koneksi Slow HTTP pada Web Server 
Pada log server akan menunjukkan jumlah koneksi. Contoh pada gambar 12 di server Apache, statusnya tampak seperti berikut:

\# apachectl status

CPU Usage: u4.2 s.23 cu.26 cs.35 - $1.28 \%$ CPU load

.242 requests $/ \mathrm{sec}-140 \mathrm{~B} / \mathrm{second}-580 \mathrm{~B} /$ request $-.111111 \mathrm{~ms} /$ request

150 requests currently being processed, 0 idle workers

Gambar 12. Status pada Web Server Apache pada Saat Serangan

Informasi di atas menunjukkan penggunaan CPU yang sangat rendah, banyak proses pada apache, sangat sedikit permintaan baru, penyerang bekerja dengan membuat banyak permintaan dan lebih banyak lagi hingga mencapai batas MaxClientsapache. Jika kita melihat pada gambar 13 logapache, itu akan seperti ini:

\# cat /var/log/apache2/error.log

[mpm_prefork:error] [pid 1431] AH00161: server reached MaxRequestWorkers

setting, consider raising the MaxRequestWorkers setting

Gambar 13. Log Error pada Apache

Perintah ini akan menyaring semua IP yang terhubung ke server, agar menghitung setiap kejadian yang sering terjadi. Outputnya seperti gambar 14:

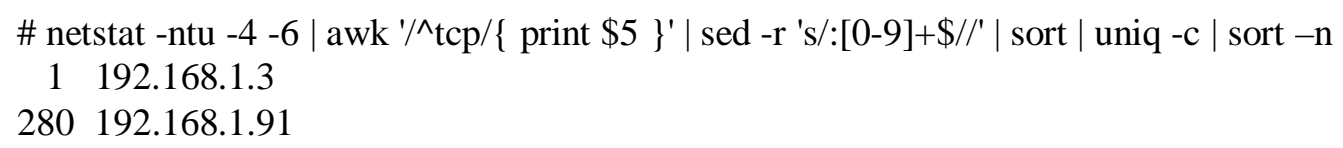

Gambar 14. Perintah Memfilter IP Address yang Banyak Mengakses Web Server

Setelah mengetahui IP penyerang, pemblokiran dapat dilakukan pada alamat IP. Pada sistem operasiLinux, tersedia aplikasi IPTABLE. Perintah berikut dapat digunakan terilihat pada gambar 15 :

$$
\text { \# iptables -A INPUT -i eth0 -s 192.168.1.91 -j DROP }
$$

Gambar 15. Firewall Iptables untuk Pemblokiran

Arti dari baris perintah di atas, jika ada koneksi masuk melalui antarmuka eth 0, dari IP sumber 192.168.1.91 lalu dilakukan (DROP). Akan tetapi hal seperti ini cukup merepotkan jika penyerang lebih banyak.

\subsection{Penelitian Terkait}

Risiko ancaman keamanan komputer oleh serangan slow HTTP telah memicu ahli keamanan jaringan komputer untuk mengembangkan teknik pertahanan. Banyak metode dan teknik pertahanan yang berbeda tersedia untuk server web. Metode-metode ini bervariasi tergantung pada objek yang dilindungi dan seperangkat aturan dalam operasi. Peneliti dari akademisi juga telah melakukan banyak penelitian untuk mendeteksi dan menangani serangan 
slow HTTP. Sejumlah besar literatur tersedia dalam serangan ini. Berikut rangkuman model atau metode yang berfokus pada penanganan serangan slow HTTP.

Referensi [6] sistem deteksi yang diusulkan adalah anomaly Sistem deteksi yang mengukur Hellinger Distance antara dua distribusi probabilitas yang dihasilkan dalam fase pelatihan dan pengujian. Pengujian sistem deteksi yang diusulkan dengan mengumpulkan lalu lintas HTTP yang disimulasikan di LAN dan Internet. Hasil menunjukkan bahwa sistem yang diusulkan mendeteksi serangan Slow Header dan Slow Message Body dengan akurasi tinggi.

Referensi [12] menganalisis serangan DoS slow read. Hasil serangan yang efisien dapat direalisasikan ketika bandwidth lebih dari $500 \mathrm{Kbps}$. Juga, peneliti menemukan pengaturan server web yang aman terhadap serangan DoS Slow Read.

Referensi [13] mempelajari serangan Slow Read, menganalisis secara rinci ancaman saat ini dan menyajikan definisi dan kategorisasi yang tepat untuk serangan tersebut. Penelitian ini bertujuan untuk memberikan kerangka kerja yang bermanfaat untuk studi bidang ini, dan untuk proposal metodologi intrusion detection.

Referensi [14] menganalisis efektivitas Serangan Slow Read oleh lingkungan jaringan virtual. Penelitian menyimpulkan bahwa menyerang oleh penyerang tunggal tidak begitu efisien. Modul security untuk server web, ModSecurity dapat membatasi panjang status keberhasilan serangan.

Referensi [15] mengusulkan dan mengevaluasi metode pertahanan terhadap serangan DoS HTTP Slow Terdistribusi dengan memutuskan koneksi serangan secara selektif dengan memfokuskan pada jumlah koneksi untuk setiap alamat IP dan durasi waktu, letak perbedaan dalam penelitan ini adalah belum menggunakan pemasangan modul antilorispada web server apache dan belum mengaktifkan modul reqtimeout.

\section{HASIL DAN PEMBAHASAN}

\subsection{Data Hasil Pengujian pada Serangan Slow HTTP / Slowloris}

Data hasil pengujian bisa dilihat pada gambar 11. Pengujian dan serangan koneksi Slow HTTP pada web server, terlihat bahwa banyak koneksi yang tidak mampu dilayani oleh web server sehingga client yang sah tidak bisa dilayani dengan baik. Gambar 16 menunjukkan koneksi yang bertubi-tubi request ke web server,

\begin{tabular}{|c|c|c|c|c|}
\hline \multicolumn{5}{|c|}{ \# netstat -nalt | grep :80 } \\
\hline tcp6 & 0 & 0 192.168.1.90:80 & 192.168.1.91:39354 & ESTABLISHED \\
\hline tcp6 & 0 & 0 192.168.1.90:80 & 192.168.1.91:39390 & ESTABLISHED \\
\hline tcp6 & 0 & 0 192.168.1.90:80 & 192.168.1.91:39394 & ESTABLISHED \\
\hline tcp6 & 0 & 0 192.168.1.90:80 & 192.168.1.91:39174 & FIN_WAIT2 \\
\hline tcp6 & 0 & 0 192.168.1.90:80 & 192.168.1.91:39220 & ESTABLISHED \\
\hline tcp6 & 0 & 0 192.168.1.90:80 & 192.168.1.91:39202 & FIN_WAIT2 \\
\hline tcp6 & 0 & 0 192.168.1.90:80 & 192.168.1.91:39188 & FIN_WAIT2 \\
\hline tcp6 & 0 & 0 192.168.1.90:80 & 192.168.1.91:39148 & FIN_WAIT2 \\
\hline tcp6 & 0 & 0 192.168.1.90:80 & 192.168.1.91:39298 & ESTABLISHED \\
\hline tcp6 & 0 & 0 192.168.1.90:80 & 192.168.1.91:39154 & FIN_WAIT2 \\
\hline tcp6 & 0 & 0 192.168.1.90:80 & $192.168 .1 .91: 39326$ & ESTABLISHED \\
\hline tcp6 & 0 & 0 192.168.1.90:80 & 192.168.1.91:39362 & ESTABLISHED \\
\hline
\end{tabular}

Gambar 16. Menunjukkan Serangan Koneksi Slow HTTP / Slowloris

\subsection{Pertahanan Terhadap Serangan Slow HTTP}

Pertahanan terhadap serangan Slow HTTP dilakukan dengan cara tertentu konfigurasi, sehingga serangan dapat dicegah atau dikurangi. Pencegahan bisa dilakukan secara spesifik 
konfigurasi dengan mengaktifkan mod_antiloris. Dalam web server apache ada modulmod_antiloris digunakan untuk mengantisipasi serangan yang perlu diaktifkan didalam apache, berikut cara mengaktifkannya pada gambar 17.

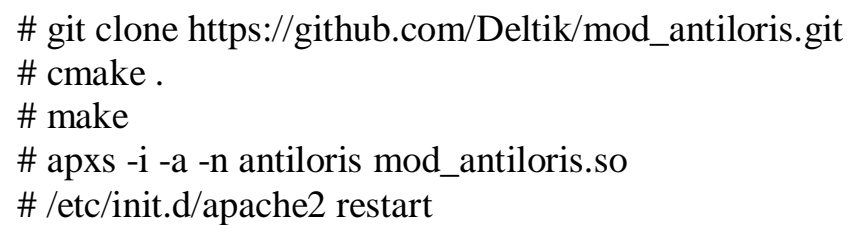

Gambar 17. Instalasi mod_antiloris berikut :

Melakukan pemeriksaan apakah mod_antiloris telah terpasang, dengan perintah sebagai

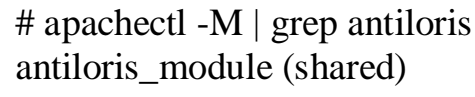

Gambar 18. mod_antiloris Telah Aktif

Jika dilakukan percobaan kembali penyerangan terhadap web server ketika mod_antiloris telah aktif bisa dilihat hasilnya pada gambar 19. Terlihat dari hasil percobaan bahwa serangan slow HTTP mampu ditangani dengan baik.

CPU Usage: u0 s.05 cu.08 cs. 13 - .0762\% CPU load

.0469 requests/sec - $48 \mathrm{~B} /$ second - $1024 \mathrm{~B} /$ request - $3.625 \mathrm{~ms} /$ request

16 requests currently being processed, 4 idle workers

Gambar 19. Hasil Serangan Ketika mod_antiloris Telah Aktif

Modul mod_reqtimeout perlu ditambahkan kendalam web server untuk menjatuhan / menolak (DROP) koneksi yang terlalu lambat tetapi klien membuka banyak koneksi. Modul mod_antiloris bekerja paling baik dalam kombinasi dengan mod_reqtimeout, karena:

a. mod_reqtimeout menjatuhkan koneksi jika terlalu lambat tetapi rentan ketika klien membuka banyak koneksi dan mencegah koneksi yang sah kehabisan waktu selama periode waktu.

b. mod_antiloris mencegah klien dari memonopoli slot koneksi tetapi tidak menjatuhkan koneksi yang lambat.

Menggunakan kedua modul pada saat yang sama melindungi terhadap kedua jenis pelaku DoS. Berikut isi file konfigurasi reqtimeout.conf dan hasil pengujian pada gambar 18 dan gambar 19. 


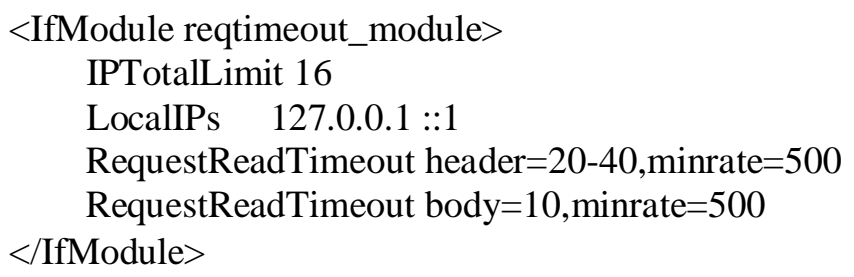

\section{Gambar 20. Isi File Reqtimeout.conf}

Pada option IP Total Limit bermaksud koneksi simultan maksimum dalam kondisi apa pun per alamat IP. Jika diatur ke 0, batas ini tidak berlaku. Pada option Request Read Timeout header $=20-40$, minrate $=500$ bermaksud tunggu maksimal 20 detik untuk byte pertama dari baris ditambah permintaan header sejak saat itu, memerlukan kecepatan data minimum 500 byte /s, tetapi jangan menunggu total lebih dari 40 detik. Hal yang perlu di ingat batas waktu lebih rendah mungkin masuk akal pada host virtual non-ssl tetapi dapat menyebabkan masalah dengan host virtual ssl yang diaktifkan, waktu habis ini mencakup waktu yang mungkin diperlukan browser untuk mengambil CRL untuk sertifikat. Jika server CRL tidak dapat dijangkau, mungkin diperlukan lebih dari 10 detik hingga browser menyerah. Pada option Request Read Timeout body $=10$, minrate $=500$ bermaksud tunggu maksimal 10 detik untuk byte pertama dari badan permintaan (jika ada) sejak saat itu, memerlukan kecepatan data minimum 500 byte/s.

CPU Usage: u. 67 s1.61 cu.63 cs 1.23 - .00525\% CPU load .00052 requests $/ \mathrm{sec}-0 \mathrm{~B} / \mathrm{second}-924 \mathrm{~B} /$ request $-2.41463 \mathrm{~ms} /$ request 14 requests currently being processed, 5 idle workers

Gambar 21. Hasil Percobaan Setelah mod_slowloris dan mod_reqtimeout Diaktifkan

Pada gambar 21 menunjukkan semakin baiknya web server menghalau serangan slow HTTP atau slowloris dengan hanya melayani pengguna yang sah dan menolak koneksi-koneksi yang hanya membebani terlihat dengan 14 requests selama proses berjalan.

\section{KESIMPULAN}

Serangan slow HTTP bisa dikatakan sangat merusak sumber daya dan sangat mengganggu pada layanan yang berbasis koneksi web server, jika tidak ditanggulangi dengan benar. Ada beberapa options tambahan penanganan web server dalam konfigurasi, setiap jenis web server tentu berbeda cara menanggulanginya.

Berdasarkan hasil pengujian dengan mengaktifkan mod_antiloris dan mod_reqtimeout mampu menanggulangi serangan slow HTTP. Akhirnya, diketahui bahwa serangan slow HTTP dapat dicegah dan bahkan dihilangkan, jika serverweb diinstal sistem keamanan yang tepat.

\section{SARAN}

Saran untuk penelitian kedepan perlu dilanjutkan dari sisi keamanan traffic jaringan yang terhubung ke sumber daya database. 


\section{UCAPAN TERIMA KASIH}

Penulis mengucapkan terima kasih kepada AMIK MDP yang telah memberikan izin melakukan percobaan pada laboratorium jaringan komputer.

\section{DAFTAR PUSTAKA}

[1] Kaspersky.com, 21-May-2019. [Online]. Available: https://www.kaspersky.com/about/press-releases/2019_a-ddos-storm-has-come-numberof-attacks-grows-after-long-period-of-decline. [Accessed: 29-jan-2020].

[2] S. Suroto, 2017, “A Review of Defense Against Slow HTTP Attack," JOIV: International Journal on Informatics Visualization, Vol. 1, No. 4, p. 127, Apr.

[3] R. Agarwal, "Defending the Network from Real IoT Threats," Security Magazine RSS, 28-Jul-2015. [Online]. Available: https://www.securitymagazine.com/articles/86545defending-the-network-from-real-iot-threats. [Accessed: 30-Jan-2020].

[4] J. Park, 2015, "Analysis of Slow Read DoS Attack and Countermeasures on Web Servers," International Journal of Cyber-Security and Digital Forensics, Vol. 4, No. 2, pp. 339-353.

[5] Burak, B. Guzel, B. Guzel, B. G. B. Guzel, and B. Guzel, "HTTP Headers for Dummies," Code Envato Tuts, 02-Dec-2009. [Online]. Available: https://code.tutsplus.com/tutorials/http-headers-for-dummies--net-8039. [Accessed: 05Feb-2020].

[6] N. Tripathi, N. Hubballi, and Y. Singh, 2016, "How Secure are Web Servers? An Empirical Study of Slow HTTP DoS Attacks and Detection," 2016 11th International Conference on Availability, Reliability and Security (ARES).

[7] D Sai Krishna et al, 2012, "Application Denial of Service Attacks Detection using Group Testing Based Approach". International Journal of Computer Science \& Communication Networks, Vol 2(2), pp. 167- 171, Feb.

[8] "How Slow HTTP Can Knock Down A Server?," Geeksfor Geeks, 23-May-2017. [Online]. Available: https://www.geeksforgeeks.org/slow-http-can-knock-server/. [Accessed: 05-Feb-2020].

[9] "Analyzing The Anatomy of a DoS Attack Using Slowloris," The Official Admin-Ahead Blog, 12-Apr-2016. [Online]. Available: https://admin-ahead.com/blog/analyzing-theanatomy-of-a-dos-attack-using-slowloris/. [Accessed: 05-Feb-2020].

[10] D. Senecal, "The Akamai Blog Subscribe," Slow DoS on the Rise - The Akamai Blog. [Online]. Available: https://blogs.akamai.com/2013/09/slow-dos-on-the-rise.html. [Accessed: 05-Feb-2020].

[11] S. Mendon, "Slow DOS Attack: Why It Is Dangerous and How to Detect Using a SIEM," Cyber Security \& Information Security Services. [Online]. Available: 
https://www.paladion.net/blogs/how-to-detect-slow-dos-attack-using-siem. [Accessed: 05-Feb-2020].

[12] S. Tayama and H. Tanaka, 2017, "Analysis of Effectiveness of Slow Read DoS Attack and Influence of Communication Environment," 2017 Fifth International Symposium on Computing and Networking (CANDAR), pp. 350-359

[13] E. Cambiaso, G. Papaleo, G. Chiola, and M. Aiello, 2013, "Slow DoS Attacks: Definition and Categorisation," International Journal of Trust Management in Computing and Communications, Vol. 1, No. 3/4, pp. 300-319.

[14] J. Park, 2015, "Analysis of Slow Read DoS Attack and Countermeasures on Web Servers," International Journal of Cyber-Security and Digital Forensics, Vol. 4, No. 2, pp. 339-353.

[15] T. Hirakawa, K. Ogura, B. B. Bista, and T. Takata, 2016, "A Defense Method Against Distributed Slow HTTP DoS Attack," 2016 19th International Conference on NetworkBased Information Systems (NBiS), pp. 152-158. 